\title{
७MONÇÕES
}

\section{Constâncias nos dissensos: o quadro normativo brasileiro e a emergência da "paradiplomacia de resistência"}

\author{
Constancy in dissensus: the brazilian legal framework and the \\ emergency of "paradiplomacy of resistance"
}

\section{Persistencia en los disensos: el marco normativo brasileño y la emergencia de La "paradiplomacia de resistencia"}

\author{
Marinana Andrade e Barros \\ Centro Universitário UNA \\ Belo Horizonte- Minas Gerais, Brasil \\ E-mail: marinana_andrade@yahoo.com.br \\ Orcid: https://orcid.org/0000-0001-7903-55190
}

\begin{abstract}
Resumo: A ação internacional de Estados e Municípios, fenômeno conhecido como paradiplomacia, vem se desenvolvendo e sistematizando no Brasil especialmente desde 1990. As tentativas de se estabelecer uma legislação geral acerca deste fenômeno foram rejeitadas no país. Há, atualmente, apenas alguns acordos internacionais realizados pelo governo federal que estabelecem a possibilidade da ação internacional de entes federados de maneira pontual. No Brasil, tradicionalmente, a paradiplomacia centra-se em ações relacionadas ao desenvolvimento econômico e social e à preservação ambiental e ocorre sem embates com o governo federal. Contudo, a recente polarização política trouxe consequências também para este âmbito, inaugurando o que aqui se nomeia "paradiplomacia de resistência", na qual estabelece-se um contraponto entre o governo federal e os governos estaduais na arena internacional. Argumenta-se neste artigo que as recentes nuances assumidas pela paradiplomacia devem ser levadas em consideração ao se discutir acerca de sua normatização sob pena de se frear um processo que tem sido importante para a realização das competências de Estados e Municípios.
\end{abstract}

Palavras-chave: Paradiplomacia; Paradiplomacia de resistência; Governos subnacionais; Quadro normativo. 


\begin{abstract}
The international action of subnational states and municipalities, a phenomenon known as paradiplomacy, has been developing and systematizing in Brazil since 1990. Attempts to establish a general legislation on this phenomenon have been rejected in the country. There are currently some international agreements made by the federal government that establish the possibility of punctual international action by federated entities. Traditionally in Brazil, paradiplomacy is centered on actions related to economic and social development and environmental preservation and occurs without clashes with the federal government. However, the recent political polarization has also brought consequences for this area, inaugurating what is here called "paradiplomacy of resistance", in which a counterpoint is established between the federal government and state governments in the international arena. It is argued in this article that the recent nuances assumed by paradiplomacy should be taken into account when discussing about its standardization, under penalty of slow down a process that has been important for the realization of the competences of subnational states and municipalities.
\end{abstract}

Keywords: Paradiplomacy; Paradiplomacy of resistance; Subnational governments; Normative framework.

Resumen: La acción internacional de Estados y Municipios, fenómeno conocido como paradiplomacia, se viene desarrollando y sistematizando en Brasil especialmente desde 1990. Los intentos de establecer una legislación general acerca del fenómeno han sido rechazadas en el país. Hay, en la actualidad, solamente algunos acuerdos internacionales realizados por el gobierno federal que establecen la posibilidad de la acción internacional de entes federados de manera puntual. En Brasil, tradicionalmente, la paradiplomacia está centrada en acciones relacionadas al desarrollo económico y social y a la preservación ambiental y ocurre sin conflictos con el gobierno federal. No obstante, la reciente polarización política ha traído consecuencias también en este ámbito, inaugurando lo que aquí se nombra como "paradiplomacia de resistencia", en la cual se establece un contrapunto entre el gobierno federal y los gobiernos estaduales en la arena internacional. En este artículo se argumenta que los recientes matices asumidos por la paradiplomacia deben ser considerados al discutir acerca de su reglamentación bajo pena de que se frene un proceso que viene siendo importante para la realización de las competencias de Estados y Municipios.

Palabras clave: Paradiplomacia; Paradiplomacia de resistencia; Gobiernos subnacionales; Marco normativo. 


\section{INTRODUÇÃO}

A ação internacional dos governos subnacionais para complementar, duplicar ou desafiar a atividade diplomática do Estado é conhecida como paradiplomacia ${ }^{1}$ (SOLDATOS, 1990). Ela ocorre no Brasil de forma sistematizada ao menos desde a década de $1990^{2}$, configurando-se como atividades empreendidas pelos Estados membros e pelos Municípios para além das fronteiras nacionais e que, como regra, têm por propósito cumprir os objetivos que Ihes são atribuídos constitucionalmente. Este movimento, composto por períodos mais ou menos dinâmicos no caso brasileiro, é parte de um fenômeno mais amplo, abrangente em termos geográficos e que tem seus primórdios na Europa no início da segunda metade do século XIX (TAVARES, 2016). Em âmbito mundial, estas ações ganharam densidade a partir da década de 1960, com o que Soldatos (1990) caracteriza como uma erosão das prerrogativas dos Estados Nacionais em relação à sua política externa. No Brasil, a redemocratização, a redefinição do modelo federativo e a crise econômica da chamada década perdida foram eventos que influenciaram o movimento de busca dos Estados e Municípios por recursos e intercâmbios com instituições estrangeiras e internacionais, públicas e privadas notadamente em acordos financeiros e de cooperação técnica.

Trata-se este de um fenômeno especialmente importante para os Estados federais. Apesar de a ação internacional de governos subnacionais não ser exclusiva de federações, ela tem se desenvolvido com alguma frequência e êxito dentro de pactos federativos, como consequência, seu marco analítico-conceitual tem como eixo as federações (BANZATTO, 2015). Para Rodrigues (2008, p. 1015), a paradiplomacia se constitui como "um dos fenômenos mais desconcertantes do federalismo na atualidade" já que a ação internacional é "possivelmente o espaço de atuação estatal e de formulação de políticas públicas em que o

\footnotetext{
${ }^{1}$ As discussões acerca da nomenclatura desse fenômeno permeiam boa parte da literatura que o analisa. Nesse artigo, opta-se pelo já consagrado termo "paradiplomacia" para nomeá-lo. Para mais sobre discussões conceituais, ver: Prado (2018), Junqueira (2017) e Tavares (2016).

2 Apesar de a robustez do fenômeno ter data relativamente recente, é possível encontrar referências importantes à existência de ação internacional dos governos subnacionais no âmbito financeiro já no século XIX. Nesse sentido, José Nelson Bessa Maia e José Flávio Sombra Saraiva (2012) analisam os casos de financiamento externo empreendidos pelos governos estaduais durante a República Velha (1890-1930).
} 
Estado-nação mais zela por exercer monopólio, coerência e controle". Ao atuar para além das fronteiras nacionais, os governos subnacionais rompem com um dos pilares das tradicionais relações internacionais, centrada na figura do Estado soberano. Diante disto, as federações optaram por caminhos diversos em termos legislativos. Parte delas adaptou suas legislações, normatizando acerca da paradiplomacia a fim de traçar suas perspectivas e seus limites. Outras optaram por não normatizar - ou ainda não normatizaram - a ação internacional dos governos subnacionais. O Brasil faz parte do grupo de Estados no qual a prática da atuação dos governos não-centrais para além das fronteiras nacionais se desenvolveu com um aparato jurídico, específico sobre a matéria, bastante restrito. Com isso, se, por um lado, faltam aos gestores públicos subnacionais diretivas sobre as possibilidades de ação na arena internacional, por outro, da ausência de normas e de demarcações e limites claros nesta seara decorre certa autonomia para sua prática.

Este artigo se propõe a analisar o quadro normativo brasileiro e suas consequências diante de um cenário que torna este um tema candente. Observa-se, neste momento, uma importante mudança em parte das atividades internacionais dos governos subnacionais consequente da intensa polarização política do país. Estados membros têm buscado cooperar diretamente com entes estrangeiros quando identificam uma ação do governo federal que tem potencial de prejudicá-los, seja com a perda de recursos financeiros ou com atividades que levam à corrosão de políticas públicas regionais. Assim, além das ações típicas de cooperação internacional, é possível perceber nesse momento uma espécie de atividade internacional dos Estados em que há um claro embate com o governo federal. Nomeia-se aqui esse fenômeno como "paradiplomacia de resistência". Trata-se de uma ação que não se aproxima da protodiplomacia - termo usado por Duchacek (1990) para nomear atividades internacionais de governos subnacionais que têm o intuito de romper com o Estado soberano e formar um novo Estado Nacional, independente. Em termos conceituais, essa nova forma de ação dos governos estaduais brasileiros estabelece-se como uma forma de paradiplomacia que em vários sentidos se aproxima daquela tradicional - respeita a representação internacional e a unicidade territorial do Estado Nacional e orienta-se a partir de competências 
constitucionalmente previstas. Assim, este tipo de ação se insere na definição de paradiplomacia proposta por Soldatos (1990). Mas, argumenta-se que, por sua singularidade, deve ser qualificada, sublinhando-se a contraposição que the é característica, ou seja, a resistência ao governo federal assumida pelos entes federados na arena internacional.

Diante deste contexto, o estudo proposto será sistematizado começando por examinar brevemente o desenvolvimento da paradiplomacia como um fenômeno global. Em seguida, passa-se à análise específica do cenário brasileiro com a caracterização tanto das atividades realizadas por Estados e Municípios quanto do aparato institucional que acompanha a ação internacional. Segue-se, então, para a investigação do quadro normativo do Brasil, buscandose compreender tanto como a legislação vigente trata a ação pública internacional quanto os esforços realizados para normatização da paradiplomacia. A qualificação da cena da paradiplomacia no Brasil se perfazerá com o exame ações internacionais que nos últimos anos têm permeado parte das atividades dos Estados brasileiros como resultado da intensa polarização política vivida no país. Feito isto, finalmente, será realizada uma análise que busca estabelecer um diálogo entre as características da paradiplomacia brasileira e as tendências de normatização do tema.

As principais estratégias metodológicas utilizadas neste artigo serão a análise documental, técnica de pesquisa realizada por meio de fontes primárias, e a pesquisa bibliográfica. Neste sentido, serão examinadas as normas e as propostas normativas já realizadas no Brasil acerca da atividade paradiplomática, tendo como fonte as bases de dados do Congresso Nacional e do Ministério das Relações Exteriores. Da mesma forma, o estudo comparativo auxiliará na compreensão das soluções encontradas em outras federações para a equação formada pela ação dos entes subnacionais no sistema internacional. Pesquisas qualitativas e quantitativas fornecerão os subsídios para a apreensão das características da paradiplomacia e sua institucionalização no Brasil. Especificamente para descrição e análise das recentes incursões internacionais de Estados membros que confrontam os posicionamentos do governo federal, serão realizadas pesquisas em mídia que auxiliarão a descrever o movimento em curso. 


\section{O DESENVOLVIMENTO DA PARADIPLOMCIA: QUANDO O SUBNACIONAL ULTRAPASSA AS FRONTEIRAS NACIONAIS}

Nesta seção, serão brevemente examinadas as formas como ocorrem os contatos internacionais perpetrados por governos locais e regionais e as motivações, ou seja, os fatores que colaboram para a existência paradiplomacia. A literatura que desvela os contornos deste fenômeno já se tornou clássica para os estudiosos do tema e segue sendo um importante guia para sua compreensão, especialmente se utilizada juntamente com trabalhos mais recentes que buscam explicitar seu desenvolvimento e acompanhar eventuais mudanças em sua trajetória.

Ao refletir sobre como se estabelecem os contatos dos governos subnacionais com o ambiente internacional, Duchacek (1990) sintetiza seis possibilidades: estabelecimento de escritórios permanentes ou de centros de comércio e indústria que representam a unidade subnacional; viagens internacionais realizadas pelos governantes; missões técnicas para coleta de informações; participação em feiras de comércio e investimentos; estabelecimento de zonas de comércio com tarifas preferenciais; e participação em conferências e organizações internacionais. Para além das possibilidades enumeradas por Duchacek, Banzatto (2015, p. 52) esclarece que a elas se somam outras, como "a cooperação técnica para implementação de políticas públicas, a criação de zonas de cooperação sub-regional, os acordos de irmanamento e a participação em redes de cidades".

As explicações, ou o porquê das ações internacionais dos governos subnacionais encontram-se tanto em fatores internos às federações quanto externos, relacionados ao desenvolvimento do sistema internacional nas últimas décadas (KEATING, 1999; ROMERO, 2004; KUZNETSOV, 2015). Internamente aos Estados Federais, são, certamente, propulsores da paradiplomacia, a divisão de competências e a autonomia atribuída às subunidades, por meio dos pactos federativos. A necessidade de os membros da federação fazerem frente às competências dispostas em suas Constituições faz com que estes busquem formas para suprir 
as demandas locais e regionais que não passem somente pelo governo central. Neste contexto, especialmente a partir da retração da participação dos Estados nas economias nacionais durante as décadas de 80 e 90, o sistema internacional passou ser percebido como um importante instrumento para o aprimoramento das políticas públicas subnacionais. Este movimento é facilitado, no caso das federações, pela viabilidade prática de uma atuação mais autônoma das unidades frente aos governos centrais, em relação ao que, geralmente, ocorre nos Estados Unitários.

Quanto ao sistema internacional, os contornos por ele assumidos nas últimas décadas se destacam como fomentadores para o desenvolvimento da paradiplomacia. Ainda que seja possível encontrar ações internacionais pontuais desde o século XIX (TAVARES, 2016), o aprofundamento deste fenômeno relaciona-se ao fim da Segunda Guerra (SASSEN, 2001) e ganha intensidade com o término da Guerra Fria. A democratização do cenário internacional é o pano de fundo desta dinâmica que se configura pela ampliação do rol de atores que dele participam. Neste sentido, vem se desenvolvendo uma importante mudança no sistema que se caracterizava pela exclusividade das relações interestatais. Apesar de os Estados Nacionais permanecerem como atores essenciais deste cenário, a aceleração dos fluxos internacionais - ou globalização - e o desenvolvimento de processos de integração regional trouxeram consigo a possibilidade de emergência de novos importantes players para o âmbito externo (KUZNETSOV, 2015).

A globalização e a integração regional influenciam diretamente a dinâmica das unidades federadas ao intensificar os fluxos transfronteiriços, fator de incremento para a paradiplomacia (FROIO, 2015). Neste sentido, atuam favoravelmente à ação internacional das subunidades, as ondas migratórias, os fluxos comerciais e os investimentos estrangeiros diretos. Especificamente no âmbito da integração regional, houve a criação de canais institucionais de inserção de governos subnacionais - como o Foro Consultivo de Municípios, Estados Federados, Províncias e Departamentos do Mercosul e o Comitê de Regiões da União Europeia. Da mesma forma, no contexto da integração e também fora dele foram criadas redes que agregam governos locais e regionais em busca de soluções para problemas em 
comum e compartilhamento de best practices - caso das redes Mercocidades, Eurocities, Cidades e Governos Locais Unidos, Associação Mundial das Grandes Metrópoles, entre tantas outras.

Nesta mesma direção, há de se mencionar a atuação das Organizações Internacionais (OI) como agentes que contribuem para ampliar a inserção dos governos subnacionais na arena internacional. Desde a década de 1990, passou-se a inclui-los em discussões acerca de questões como pobreza, meio ambiente, desenvolvimento sustentável e grupos vulneráveis. Houve, a partir de então, uma clara vocalização dos organismos internacionais a favor da ação externa dos entes subnacionais (TAVARES, 2016). A percepção é de que os níveis local e regional precisam participar dos diálogos que buscam respostas a estes problemas. Os governos subnacionais fizeram parte das grandes conferências das Nações Unidas ${ }^{3}$ (RODRIGUES, 2004) e de algumas das iniciativas internacionais mais importantes das últimas décadas para enfrentamento de problemas globais, tais quais os Objetivos do Milênio ${ }^{4}$ (ODM) e os Objetivos do Desenvolvimento Sustentável ${ }^{5}$ (ODS). Parte-se, assim, da perspectiva de que a resolução dos grandes problemas que afligem os Estados passa pelo âmbito subnacional.

\section{CARACTERÍSTICAS DA PARADIPLOMACIA NO BRASIL: 0 INTERNACIONAL COMO MEIO PARA O DESENVOLVIMENTO LOCAL E REGIONAL}

Às motivações internacionais para o desenvolvimento da paradiplomacia, somam-se estímulos no âmbito nacional que, no caso do Brasil, levam entes federativos a considerarem, entre as atividades da Administração Pública, ações que ultrapassam as fronteiras estatais.

\footnotetext{
${ }^{3}$ Entre as principais conferências estão a Eco/92, Habitat/96 e a World Summit for Children.

${ }^{4}$ Entre as principais iniciativas que comprovam esta perspectiva dos ODM estão a realização de seminários "Objetivos de Desenvolvimento do Milênio e os Governos Subnacionais" e a criação da "Rede Objetivos do Milênio América Latina e Caribe", a qual agrega cidades que se comprometeram com os Objetivos.

${ }^{5}$ Entre os ODS, o objetivo 11 é dirigido especificamente para o esforço em prol de cidades e comunidades sustentáveis.
} 
Nesta seção, será analisado o desenvolvimento da paradiplomacia no Brasil, indicando seus principais impulsos e as características das ações internacionais realizadas pelos governos estaduais e municipais. Pretende-se, assim, construir um quadro geral da prática paradiplomática no país, atentando-se para o grau de institucionalização desta temática no âmbito da Administração Pública subnacional e para os objetivos buscados. Os contornos deste fenômeno no Brasil serão apresentados apoiando-se em estudos quantitativos e qualitativos realizados por diferentes pesquisadores e instituições nos últimos anos com o objetivo de mapear este fenômeno.

A atividade paradiplomática não ocorre, como seria de se prever, de forma homogênea e coordenada entre os entes subnacionais brasileiros. A assimetria entre os entes federados, apontada de forma geral como propulsor da paradiplomacia (SOLDATOS, 1990; KUZNETSOV, 2015), é parte da dinâmica do fenômeno no caso brasileiro (SCHIAVON, 2019) e constrange sua prática. As ações internacionais dos governos estaduais e municipais são muitas vezes ocasionais, informais e pouco sistematizadas. Além disso, em alguma medida, o processo de internacionalização é afetado pela alternância de governos e pelo partido político no poder (BRIGAGAO, 2005; CNM, 2009; BUENO, 2010; MATSUMOTO, 2011; FROIO, 2015), assim como pelas características pessoais dos líderes do Poder Executivo subnacional (LESSA, 2007; FROIO, 2015). As pesquisas quantitativas que se debruçam sobre a internacionalização dos governos subnacionais brasileiros apontam para a percepção deste como sendo um tema importante tanto para Administrações Públicas estaduais como municipais. O estudo conduzido por Froio em 2015 com gestores estaduais conclui que, então, 72,9\% consideravam a área de relações internacionais relevante. Nos Municípios, os dados do estudo mais abrangente já realizado, conduzido pela Confederação Nacional de Municípios de 2009, indicavam que mais de $60 \%$ demonstravam interesse por assuntos internacionais.

O interesse não se converte, necessariamente, em uma sistematização institucional para a internacionalização, especialmente no caso dos Municípios, que geralmente encontram dificuldades financeiras e de pessoal para conceber uma estrutura burocrática permanente que lide com a paradiplomacia. Há bastante variedade nas formas de institucionalização da 
ação internacional de Estados e Municípios (BRIGAGÃO, 2005). O estudo de Froio (2015) identificou que, entre 1999 e 2014, todos os Estados brasileiros e o Distrito Federal tiveram, em algum momento, uma estrutura institucional para lidar com ações internacionais. Em relação aos Municípios, a pesquisa da CNM (2009) contatou então todos os 5562 governos municipais. Desses, 30, ou seja, 0,54\% possuíam um setor da Prefeitura destinado à gestão da paradiplomacia. Outros 116 possuíam um funcionário responsável pelas relações internacionais municipais (CNM, 2009). Alguns anos depois, em 2012, o Instituto Brasileiro de Geografia e Estatística (IBGE) incluiu na pesquisa sobre o perfil dos Municípios brasileiros questão similar. Dos 5565 municípios, então 113 possuíam área ou funcionário responsável pelo processo de internacionalização (IBGE, 2013).

As motivações dos governos subnacionais brasileiros para agir internacionalmente acompanham a sistematização proposta por Keating (1999). Para o autor, a paradiplomacia se desenvolve tendo como fundamentos fatores econômicos, políticos e culturais. Estudos realizados com os governos estaduais indicam que a questão econômica é o eixo do processo de internacionalização destes entes (BUENO, 2010; FROIO, 2015). As pesquisas de Bueno (2010) encontraram, na seguinte ordem, as motivações mais importantes para as missões dos Estados membros brasileiros para o exterior nos anos de 2007-2008: comércio exterior e atração de investimentos; meio ambiente; financiamento internacional; relações políticas; e gestão pública. A pesquisa de Froio (2015), realizada alguns anos depois, encontrou resultado similar ao questionar os gestores estaduais acerca da ordem de importância das motivações estaduais ao empreenderem atividades internacionais: busca de investimentos externos; captação de recursos financeiros; busca de cooperação técnica internacional; promoção do comércio exterior; promoção do turismo internacional; projeção política; e tratamento de questões fronteiriças.

Nos Municípios, as respostas obtidas pela CNM (2009) mostram resultados diferentes daqueles encontrados nos Estados. Os Municípios que possuem um órgão de relações internacionais priorizam as seguintes áreas, na ordem: cooperação técnica, captação de recursos internacionais, assessoria ao gabinete do Prefeito, comércio exterior, fomento ao 
turismo. As conclusões obtidas a partir do modelo estatístico proposto por Matsumoto (2011) apontam que as questões políticas seriam o fator mais relevante para a ação internacional dos Municípios brasileiros, contrastando com as motivações dos Estados membros, para os quais os aspectos econômicos preponderam.

O quadro obtido a partir dos dados apresentados mostra o contexto geral da paradiplomacia no Brasil, que pode ser sintetizado nas seguintes ilações: o interesse dos governos estaduais e municipais em se internacionalizar existe, mas não é necessariamente acompanhado por uma organização institucional do poder público para sua realização; a prática da paradiplomacia tem como objetivos especialmente o desenvolvimento econômico e social e a preservação ambiental. A atividade paradiplomática brasileira tende a se centrar em financiamentos tomados de instituições financeiras internacionais, acordos de cooperação técnica com instituições estrangeiras ou internacionais, missões comerciais para promoção de produtos e serviços e ações para atração de turismo e de investimento estrangeiro direto.

A abordagem tradicional dos entes federativos brasileiros em relação à paradiplomacia torna raros os embates com o governo federal. Há, no âmbito federal, uma clara tentativa de "acomodar tal processo" (MIKLOS, 2011, p. 87). É possível constatar ao longo dos anos tentativas de se ajustar institucionalmente à existência da paradiplomacia com a criação de órgãos que acompanham este fenômeno a partir da estrutura da Administração Pública. Nesse sentido, desde 1997 há uma adaptação do arranjo do Ministério das Relações Exteriores para lidar com a ação internacional dos governos estaduais e municipais. Atualmente funcionam, de acordo com o Decreto 9683 de janeiro de 2019, que dispõe sobre a estrutura regimental do MRE, a Assessoria de Relações Federativas com o Congresso e os Escritórios de Representação Regional do Ministério das Relações Exteriores (BRASIL, 2019). A criação de canais de comunicação acerca da paradiplomacia no âmbito federal mostra o reconhecimento de certa legitimidade das ações internacionais dos governos subnacionais (RODRIGUES, 2008) e um esforço de lidar com a paradiplomacia institucionalmente. 


\section{O QUADRO NORMATIVO BRASILEIRO ACERCA DA AÇÃO INTERNACIONAL DOS GOVERNOS SUBNACIONAIS}

Na última seção, foram analisadas as características da paradiplomacia no Brasil a fim de se construir uma imagem que permita conhecer esse fenômeno em seus aspectos gerais. Nesta seção, será analisada a perspectiva jurídica da paradiplomacia, considerando-se a legislação brasileira, tal qual ela se apresenta em relação às competências dos governos federal, estaduais e municipais e os esforços para a normatização da ação internacional dos entes federativos. Para tanto, serão examinadas a legislação brasileira, assim como o direito comparado, para compreender os possíveis caminhos deste fenômeno em termos jurídicos.

A atuação internacional de Estados e Municípios brasileiros foi impulsionada fundamentalmente por três fatores internos: redemocratização, novos contornos do pacto federativo dispostos na Constituição Federal de 1988 e ruptura do padrão de financiamento público da União às demais unidades federadas. A redemocratização permitiu maior vocalização das demandas populares ao poder público em uma federação agora mais descentralizada e que passou a contar com o Município como ente federado. Isto ocorreu ao mesmo tempo em que a erosão da capacidade fiscal da União diminuiu sua condição de articulação com os governos subnacionais (AFFONSO, 1994). Nesse contexto, o ambiente externo apareceu como uma alternativa importante para que os governos subnacionais enfrentassem os problemas políticos, econômicos e sociais (BARRETO, 2001).

Constitucionalmente, as disposições sobre a ação externa consideram, expressamente, esta atividade como parte das competências da União. Nesse sentido, dispõem o artigo $21^{6}$ sobre relações da União com outros Estados e com Ols, o artigo $49^{7}$ atenta para a competência do Congresso Nacional para resolver sobre tratados e atos

\footnotetext{
${ }^{6}$ Art. 21 - Compete à União: I - manter relações com Estados estrangeiros e participar de organizações internacionais (...).

${ }^{7}$ Art 49 - É da competência exclusiva do Congresso Nacional: I - resolver definitivamente sobre tratados, acordos ou atos internacionais que acarretem encargos ou compromissos gravosos ao patrimônio nacional (...)
} 
internacionais, o artigo $52^{8}$ esclarece sobre a competência do Senado Federal para autorizar financiamentos internacionais e, finalmente, o artigo $84^{9}$ atribui ao Presidente da República a direção das relações exteriores. As relações públicas internacionais são uma das dimensões da repartição de competências que comprova o fato apontado por Magalhães (2000), para quem o Brasil segue sendo um Estado federal profundamente centralizado em torno da União. Apenas o financiamento internacional das subunidades federadas é previsto constitucionalmente, disposto no artigo 52, V. Com relação à repartição de competências, na Constituição de 1988 estão elencadas as competências comuns, no artigo $23^{10}$, que são deveres da União, Estados, Distrito Federal e Municípios. As competências concorrentes, que devem ser visadas pela União, Estados membros e Distrito Federal estão previstas no artigo

\footnotetext{
${ }^{8}$ Art. 52 - Compete privativamente ao Senado Federal: V - autorizar operações externas de natureza financeira, de interesse da União, dos Estados, do Distrito Federal, dos Territórios e dos Municípios; VIII - dispor sobre limites e condições para a concessão de garantia da União em operações de crédito externo e interno.

${ }^{9}$ Art. 84 - Compete privativamente ao Presidente da República: VII - manter relações com Estados estrangeiros e acreditar seus representantes diplomáticos; VIII - celebrar tratados, convenções e atos internacionais, sujeitos a referendo do Congresso Nacional; XIX - declarar guerra, no caso de agressão estrangeira, autorizado pelo Congresso Nacional ou referendado por ele, quando ocorrida no intervalo das sessões legislativas, e, nas mesmas condições, decretar, total ou parcialmente, a mobilização nacional; XX - celebrar a paz, autorizado ou com o referendo do Congresso Nacional.

${ }^{10}$ Art. 23 - É competência comum da União, dos Estados, do Distrito Federal e dos Municípios: I - zelar pela guarda da Constituição, das leis e das instituições democráticas e conservar o patrimônio público; Il - cuidar da saúde e assistência pública, da proteção e garantia das pessoas portadoras de deficiência; III - proteger os documentos, as obras e outros bens de valor histórico, artístico e cultural, os monumentos, as paisagens naturais notáveis e os sítios arqueológicos; IV - impedir a evasão, a destruição e a descaracterização de obras de arte e de outros bens de valor histórico, artístico ou cultural; $\mathrm{V}$ - proporcionar os meios de acesso à cultura, à educação e à ciência; $\mathrm{V}$ - proporcionar os meios de acesso à cultura, à educação, à ciência, à tecnologia, à pesquisa e à inovação; VI proteger o meio ambiente e combater a poluição em qualquer de suas formas; VII - preservar as florestas, a fauna e a flora; VIII - fomentar a produção agropecuária e organizar o abastecimento alimentar; IX - promover programas de construção de moradias e a melhoria das condições habitacionais e de saneamento básico; $\mathrm{X}$ combater as causas da pobreza e os fatores de marginalização, promovendo a integração social dos setores desfavorecidos; XI - registrar, acompanhar e fiscalizar as concessões de direitos de pesquisa e exploração de recursos hídricos e minerais em seus territórios; XII - estabelecer e implantar política de educação para a segurança do trânsito.
} 
$24^{11}$, as residuais dos Estados no artigo $25^{12}$ e as competências dos Municípios disposta no artigo $30^{13}$. Não há, nas disposições de competências comuns, concorrentes ou específicas dos Municípios, menção à atuação em âmbito internacional.

A Constituição de 1988 seguiu, assim, a sistemática de todas as Cartas Constitucionais do Brasil Republicano ao dispor sobre a competência do Presidente para atuação internacional. A compreensão de que a ação internacional seria ato do Poder Executivo Federal foi corroborada pelos pareceres do Itamaraty sobre a atuação externa das subunidades nacionais (MEDEIROS, 2000). Há questionamentos ao Itamaraty sobre a viabilidade de atos internacionais de governos estaduais e municipais desde a década de 1930. Os pareceres versaram sobre as seguintes possibilidades: de o Estado de São Paulo ingressar em juízo devido a um empréstimo externo (1937) e de realizar acordo com a Organização Internacional para Refugiados (1951); de a Assembleia Legislativa da Guanabara declarar um representante diplomático estrangeiro como persona non grata (1963); e de os Municípios

${ }^{11}$ Art. 24. Compete à União, aos Estados e ao Distrito Federal legislar concorrentemente sobre: I - direito tributário, financeiro, penitenciário, econômico e urbanístico; II - orçamento; III - juntas comerciais; IV - custas dos serviços forenses; $V$ - produção e consumo; VI - florestas, caça, pesca, fauna, conservação da natureza, defesa do solo e dos recursos naturais, proteção do meio ambiente e controle da poluição; VII - proteção ao patrimônio histórico, cultural, artístico, turístico e paisagístico; VIII - responsabilidade por dano ao meio ambiente, ao consumidor, a bens e direitos de valor artístico, estético, histórico, turístico e paisagístico; IX - educação, cultura, ensino, desporto, ciência, tecnologia, pesquisa, desenvolvimento e inovação; $X$ - criação, funcionamento e processo do juizado de pequenas causas; XI - procedimentos em matéria processual; XII - previdência social, proteção e defesa da saúde; XIII - assistência jurídica e Defensoria pública; XIV - proteção e integração social das pessoas portadoras de deficiência; XV - proteção à infância e à juventude; XVI - organização, garantias, direitos e deveres das polícias civis.

${ }^{12}$ Art. 25. Os Estados organizam-se e regem-se pelas Constituições e leis que adotarem, observados os princípios desta Constituição. § 1응 São reservadas aos Estados as competências que não Ihes sejam vedadas por esta Constituição. § 20 Cabe aos Estados explorar diretamente, ou mediante concessão, os serviços locais de gás canalizado, na forma da lei, vedada a edição de medida provisória para a sua regulamentação.

${ }^{13}$ Art. 30 - Compete aos Municípios: I - legislar sobre assuntos de interesse local; II - suplementar a legislação federal e a estadual no que couber; III - instituir e arrecadar os tributos de sua competência, bem como aplicar suas rendas, sem prejuízo da obrigatoriedade de prestar contas e publicar balancetes nos prazos fixados em lei; IV - criar, organizar e suprimir distritos, observada a legislação estadual; V - organizar e prestar, diretamente ou sob regime de concessão ou permissão, os serviços públicos de interesse local, incluído o de transporte coletivo, que tem caráter essencial; $\mathrm{VI}$ - manter, com a cooperação técnica e financeira da União e do Estado, programas de educação pré-escolar e de ensino fundamental; VI - manter, com a cooperação técnica e financeira da União e do Estado, programas de educação infantil e de ensino fundamental; VII - prestar, com a cooperação técnica e financeira da União e do Estado, serviços de atendimento à saúde da população; VIII - promover, no que couber, adequado ordenamento territorial, mediante planejamento e controle do uso, do parcelamento e da ocupação do solo urbano; IX - promover a proteção do patrimônio histórico-cultural local, observada a legislação e a ação fiscalizadora federal e estadual. 
realizarem acordo com pessoa jurídica de Direito Internacional Público (1999). Em todos os casos, o Itamaraty respondeu negativamente à intenção de ação externa do governo subnacional argumentando sua inconstitucionalidade ainda que tendo como parâmetros diferentes paradigmas constitucionais (MEDEIROS, v. 3, v.4, v. 6, 2000).

Ao optar por prever a paradiplomacia como atividade de competência dos governos subnacionais, entende-se que a Carta Magna deve ser o instrumento para dispor acerca do tema, assim como para estabelecer seus limites (REZEK, 2005). No direito comparado, observa-se, efetivamente uma tendência a normatizar a paradiplomacia por meio de reformas constitucionais. Foi o que ocorreu na Bélgica, com a reforma constitucional de 1993, na Argentina, em 1994 e na Áustria, em 2002. Nos casos de Bélgica e Áustria, o federalismo já tendia à descentralização, com ampla autonomia dos governos subnacionais, que foram ampliadas a partir do abrandamento da exclusividade de o governo central pactuar internacionalmente (LESSA, 2002). Diferente foi o caso da Argentina, cujo federalismo foi extremamente concentrado em seu início e tendeu a uma maior centralização ao longo das décadas devido a fatores políticos e históricos. Neste caso, a constitucionalização da paradiplomacia veio a conceder um caráter mais equilibrado ao pacto federativo nacional (BANZATTO, 2015).

Uma das poucas exceções foi a compreensão desta questão na federação mexicana, que optou por normatizar a paradiplomacia por meio de uma lei infraconstitucional. Não obstante a discordância veemente de constitucionalistas pátrios quanto à adequação deste diploma (ABRAHAM, 2007), desde 1992, vigora no México a "Lei de Celebração de Tratados", que amplia a possibilidade de participação internacional com certa autonomia por parte dos entes subnacionais, inclusive Municípios.

No Brasil, houve uma tentativa de constitucionalização da matéria e esforços de normatização no âmbito infraconstitucional. Em 2005, foi enviada ao Congresso Nacional, a Proposta de Emenda à Constituição (PEC) no 475, que dispunha acerca da possibilidade de Estados, Municípios e Distrito Federal agirem internacionalmente. Fazia-o por meio de um acréscimo ao dispositivo constitucional que trata das competências comuns aos entes 
federados. Vigorando a proposta, passaria a dispor a Constituição que os entes subnacionais poderiam promover atos e celebrar acordos ou convênios com governos subnacionais estrangeiros, desde que respeitadas as competências constitucionais a cada ente atribuídas, observadas as competências exclusivas da União e mediante prévia autorização da União. Lei posterior deveria regulamentar de forma exata os procedimentos para que tais acordos e convênios internacionais fossem celebrados. A Comissão de Constituição e Justiça e de Cidadania do Congresso Nacional seguiu o relator e argumentou que a ausência de permissão expressa na Constituição acerca da possibilidade de ação internacional dos membros federados não seria motivo suficiente para compreender que isto seria proibido, optando então por arquivar a Proposta (CAMARA, 2006).

Em 2006, teve início a tramitação no Congresso de uma Proposta de Substitutivo ao Projeto de Lei do Senado (PLS) no 98 que dispôs sobre a possibilidade de Estados, Municípios e Distrito Federal agirem externamente, no âmbito de suas competências constitucionais, por meio da assinatura de convênios regidos por lei estadual ou municipal os quais deveriam ser objeto de apreciação prévia do MRE. A proposta foi rejeitada em 2010 (SENADO, 2010). O exato procedimento e eventual prazo para apreciação realizada pelo MRE aos convênios internacionais não foram mencionados pela Proposta de Substitutivo.

Ainda que tenha havido o arquivamento tanto da PEC quanto da Proposta de Substitutivo, ambas trouxeram consigo importantes discussões sobre os limites da paradiplomacia. De formas diferentes, as propostas dispuseram sobre a perspectiva de o governo federal aprovar previamente os atos internacionais dos governos estaduais e municipais. A PEC estipulava que a União deveria autorizar previamente os atos, acordos e convênios realizados com entes subnacionais estrangeiros. Já a Proposta de Substitutivo dispunha sobre apreciação do MRE aos convênios realizados pelos governos subnacionais. No caso da Proposta de Substitutivo, era explícito que o objeto de apreciação do MRE seria em relação à pactuação de compromissos jurídicos. Na PEC, mencionava-se a possibilidade de governo subnacional "promover atos e celebrar acordos ou convênios mediante prévia autorização da União". Não fica claro se somente os compromissos jurídicos internacionais 
deveriam passar pelo crivo da Administração Federal ou se qualquer ato praticado por governos estaduais e municipais para além das fronteiras nacionais deveria ser objeto de apreciação. Há, no Brasil, 24 Estados membros, o Distrito Federal e, segundo dados do IBGE (2020), 5570 Municípios. Ainda que o número de Municípios que efetivamente praticam a paradiplomacia seja relativamente baixo, a aprovação em tempo razoável de todos os acordos e/ou "atos" internacionais realizados por todos os governos subnacionais brasileiros parece pouco crível.

A aprovação pelo governo federal não seria uma originalidade, caso as propostas tivessem seguido adiante. Trata-se este do constrangimento jurídico mais comum à paradiplomacia e que tem uma implicação negativa à sua dinâmica. As ações internacionais dos governos não-centrais costumam se iniciar antes mesmo de alguma referência constitucional nesse sentido - como é o caso do Brasil -, assim, quando a matéria é constitucionalizada e passa-se a exigir que todo ato seja previamente aprovado por um órgão do governo central, parte da celeridade deste movimento se perde. Algumas soluções interessantes foram encontradas para enfrentar este problema. Na Áustria, segundo a Constituição de 1920, reformada em 2002, o governo federal deve ser comunicado, pelo governador do Land, antes de serem iniciadas as negociações de um acordo internacional e este tem um prazo para responder sobre a demanda (AUSTRIA, 1920). Após o recebimento do pedido de aprovação, o governo tem oito semanas para se pronunciar. Não havendo negativa neste ínterim, é dado como aceito tacitamente o pedido para que o governo estadual dê início às negociações (AUSTRIA, 1920).

Outro caso interessante é o dos Estados Unidos. A Constituição Federal afirma que as subunidades federadas podem acordar no âmbito externo, com anuência do Congresso para que o acordo possa ser efetivado (EUA, 1876). A princípio, compreendeu-se que o Congresso deveria ser consultado sobre qualquer atuação externa dos governos não-centrais. Esta interpretação foi modificada com a intensificação da atividade internacional dos governos subnacionais. O Congresso Nacional norte-americano definiu que somente os acordos que se relacionem à segurança e às diretrizes da política externa nacional devem ser objeto de 
apreciação. Dessa forma, respeita-se tanto a necessidade de agilidade das atividades paradiplomáticas quanto as funções consideradas mais fundamentais ao Legislativo norteamericano (BRANCO, 2006).

Outra restrição disposta tanto na PEC quanto na Proposta de Substitutivo é a de que os governos estaduais e municipais tratassem apenas de assuntos relacionados aos seus respectivos âmbitos de competência. Trata-se este de um constrangimento comum e bastante compreensível para a paradiplomacia. A Constituição Suíça, por exemplo, prevê a possibilidade de celebração de acordos entre os Cantões e Estados estrangeiros, devendo estes se limitar às competências dos entes federados (SUÍçA, 1999). Na mesma direção seguem a Constituição Alemã, que indica a possibilidade de os Estados membros celebrarem acordos internacionais no âmbito de suas competências (ALEMANHA, 1949) e a Constituição Austríaca que dispõe aos Länder ser permitido concluir tratados com subunidades de Estados vizinhos à Áustria ou com os próprios Estados Nacionais desde que dentro das competências a eles atribuídas (AUSTRIA, 1920).

Com menor assiduidade, há casos em que os entes federados apenas tratam de temas relacionados às suas competências exclusivas, tendo uma margem de atuação mais reduzida no que concerne ao número de assuntos tratados. Apesar de a Constituição da Bélgica prever a possibilidade de acordos a serem realizados pelas comunidades e regiões em matéria de sua competência (BELGICA, 1831), na prática, tais acordos se dão, sobretudo, em matéria de educação e cultura, cuja competência é exclusiva dos Estados membros (LESSA, 2002). Pragmaticamente, há, portanto, uma repartição de competências em relação à matéria dos acordos internacionais.

O fato é que, sem exceção, os ordenamentos jurídicos que preveem a paradiplomacia resguardam aos governos não-centrais permissão para tratar somente de questões consideradas de low politics ${ }^{14}$, ou seja, comércio, cultura e assuntos que não estejam

\footnotetext{
${ }^{14}$ É comum a discussão sobre a real possibilidade de classificação de assuntos como low politics e high politics, já que, em um mundo interdependente tais temas tendem a se tangenciar com alguma frequência. Nesse sentido, ver: Ripsman (2004).
} 
diretamente relacionados às temáticas da soberania ou da segurança nacional. Tal fato pode ser apreendido da própria dinâmica constitucional dos Estados Federais, que atribui ao governo central a competência para cuidar de assuntos afeitos às high politics.

No Brasil, os esforços para normatização da paradiplomacia aprovados e vigentes relacionam-se a ações bastante pontuais. Tratam-se de acordos associados a projetos específicos ou com partes determinadas. Nesse sentido, foram realizados dois acordos que deram margem à ação internacional de governos estaduais (LESSA, 2002). Em 1996, foi assinado o Acordo de Cooperação Científica e Tecnológica entre a República Federativa do Brasil e o Governo da República Argentina sobre Atividades de Cooperação entre o Estado do Rio Grande do Sul e a Secretaria de Ciência e Tecnologia da Presidência da Nação Argentina. O documento em vigor dispôs ao governo do Rio Grande do Sul a coordenação das atividades nele elencadas (MRE, 2020). Nessa mesma linha, foi assinado o Memorando de Entendimento entre o Governo da República Federativa do Brasil e a Organização das Nações Unidas para Apoio a Atividades de Cooperação e de Intercâmbio em Administração Pública em 2001 com o objetivo de implementar o Centro Internacional de Inovação e Intercâmbio em Administração Pública no âmbito do Governo da Bahia (LESSA, 2002).

A estes esforços somaram-se dois Protocolos Adicionais aos Acordos de Cooperação Básica assinados pelo governo federal com a França e com a Itália em 2007 e que estabelecem quadros de referência para o desenvolvimento da paradiplomacia. O Protocolo com a Itália foi promulgado em 2010 por meio do Decreto $n^{\circ} 7400$ de 22 de dezembro de 2010 e aquele assinado com a França, em 2017 pelo Decreto $n^{\circ} 9139$ de 22 de agosto de 2017. Os documentos dispõem sobre a possibilidade de os governos subnacionais brasileiros pactuarem com subunidades políticas ou administrativas francesas e italianas com prévio conhecimento das autoridades nacionais - o Ministério das Relações Exteriores, no caso brasileiro. Eles reforçam, assim, a tese de que se trata, a cooperação internacional dos governos subnacionais, de uma concessão do governo federal. $\mathrm{O}$ artigo segundo de ambos os Protocolos dispõe que "[a]s Partes reconhecem aos respectivos governos locais e regionais a possibilidade de estabelecerem formas de entendimento com entidades congêneres 
relacionadas às atividades de cooperação", devendo ser estes entendimentos "previamente levados ao conhecimento das autoridades nacionais competentes" (BRASIL, 2010; BRASIL, 2017). São previstas atividades como envio de peritos, pessoal técnico, consultores, envio de bens, concessão de bolsas de estudos, participação financeira em projetos, entre outras ações que devem partir (BRASIL, 2010; BRASIL, 2017). O parecer do Itamaraty sobre os Protocolos foi favorável ao seu conteúdo, ressaltando que a Constituição somente autoriza a atividade internacional do Estado Nacional e que a ação dos governos subnacionais para além das fronteiras nacionais, reconhecida sua importância, pode se desenvolver no âmbito dos acordos-marco estabelecidos pelo governo federal (ITAMARATY, 2008).

À exígua legislação acerca da paradiplomacia no âmbito federal, somam-se normas municipais e estaduais sobre a ação internacional destes entes. Geralmente, as legislações subnacionais relacionam-se à criação de setores ou funções responsáveis pelas atividades internacionais na esfera da Administração Pública ${ }^{15}$ ou dispõem sobre uma ação para a qual a legislação traça diretivas - irmanamento ou cooperação técnica, por exemplo ${ }^{16}$. Tais normas visam a orientar tanto a organização institucional quanto as ações desenvolvidas pelos governos municipais e estaduais no âmbito internacional.

\section{UMA PARADIPLOMACIA DE RESISTÊNCIA?}

A história da ação internacional dos governos subnacionais no Brasil tem tradicionalmente alguns pontos poucos de tensão que envolvem especialmente a relação de governos estaduais com o governo federal. Nesse sentido, podem ser citadas a estatização de subsidiárias de multinacionais americanas pelo governo do Rio Grande do Sul em 1962 e a moratória do Eurobônus por Minas Gerais em 1999 (PRADO, 2018). Trataram-se de episódios

\footnotetext{
${ }^{15}$ Nesse sentido, podem ser citados o Decreto no 29.459 de 26 de fevereiro de 2016 do Município de Recife que cria e regulamenta a Chefia de Gabinete de Representação e Relações Internacionais; o Decreto no 60.038, de 31 de dezembro de 2020 do Município de São Paulo, que reorganiza os órgãos públicos municipais, entre eles a Secretaria Municipal de Relações Internacionais; o Decreto no 47.686, de 26 de julho de 2019 do Estado de Minas Gerais, que define a estrutura administrativa estadual, entre os órgãos dispostos estão a Assessoria de Relações Internacionais do Governador e a Assessoria de Cooperação Nacional e Internacional.

${ }^{16}$ Nesse sentido, a Lei no 3442 de novembro de 2018 do Município de Aparecida de Goiânia sobre cidades irmanadas; e a Lei no 12367 de dezembro de 2011 que declara o irmanamento entre o Estado da Bahia, no Brasil, e a Província de Chongqing, na China.
} 
pontuais e que se distanciam da regra geral da prática da atividade internacional dos Estados membros brasileiros. É, contudo, possível perceber um movimento nos últimos anos que merece análise mais detida. Em muitos sentidos, tem-se testemunhado um novo capítulo da história política brasileira que tem como elemento desencadeador uma intensa polarização política e como parte fundamental a eleição do Presidente Jair Bolsonaro em 2018, cujo discurso aponta para a extrema direita do espectro ideológico.

A paradiplomacia, assim como tantas outras dimensões da política nacional, passa por transformações instigadas pelo novo contexto político. Constata-se, desde 2019, um tipo original de ação internacional que tem como atores especialmente Estados geridos por governadores antagônicos ao governo Bolsonaro. A estas ações dos governos subnacionais, em que há um elemento internacional, qual seja, uma atividade que se realiza para além das fronteiras nacionais, e a clara contraposição ao governo federal, está-se aqui denominando "paradiplomacia de resistência", no sentido de que, por meio delas, desafia-se o corolário político engendrado pelo poder central.

Esta seção tem por objetivo identificar e caracterizar esta dinâmica extremamente nova na cena brasileira. Alguns estudos analíticos e, pela contemporaneidade da problemática, notícias da imprensa auxiliarão na empreitada de examinar atividades paradiplomáticas que tiveram como intuito driblar as ações do governo federal. Tratam-se de ações nas esferas ambiental, comercial e de enfrentamento da pandemia do novo coronavírus. Em todos os casos há uma nítida contraposição entre o que buscam os governadores e o que prega o governo federal. E, em todos eles, as ações empreendidas pelos entes federados estão relacionadas a suas competências constitucionalmente previstas especialmente àquelas comuns e concorrentes.

A postura de Bolsonaro em relação às questões ambientais tem sido de minimizar o problema do desmatamento e das queimadas que atingem alguns dos mais relevantes biomas brasileiros. A repercussão negativa dos dados de 2019 do Instituto de Nacional de Pesquisas Espaciais (INPE) sobre o desmatamento da Amazônia foi agravada pela desqualificação do Presidente, que minorou a importância das informações. Como consequência, o Fundo 
Amazônia, projeto para captação de recursos para preservação da região gerido pelo Banco Nacional do Desenvolvimento (BNDES) desde 2008, foi suspenso por dois de seus mais importantes doadores - Alemanha e Noruega, responsáveis por $99 \%$ dos $\mathrm{R} \$ 3,3$ bilhões do Fundo (DW, 2020). Os governadores, especialmente dos Consórcios do Nordeste ${ }^{17}$ e da Amazônia Legal ${ }^{18}$, reuniram esforços para a formação de uma frente de ação internacional em que debateram a proteção da região amazônica em foros internacionais como a Conferência do Clima da Organização das Nações Unidas e a Conferência de Paris e discutiram a renegociação do Fundo diretamente com líderes europeus (PRADO, JUNQUEIRA, 2020). A conduta dos governadores, de clara oposição às ações do Presidente em relação ao tratamento das questões ambientais, no âmbito internacional, mostra uma disposição para expor uma frente política distinta daquela do governo federal.

Outros fatos recentes que demonstraram um rompimento com a visão de unicidade do Estado no âmbito internacional estão na esfera do enfretamento da pandemia do COVID19, que contrapôs de forma recorrente os governos federal e estaduais e, por vezes também as Prefeituras. O contexto da pandemia no Brasil é amplamente conhecido. O que a princípio seria difícil apenas com o que havia em termos objetivos - enfrentar uma pandemia em um país desigual em período de adversidade econômica - tornou-se uma tarefa de complexidade ímpar ao ser lançada no campo ideológico. O negacionismo do governo federal encontrou raros ecos nos governos estaduais que se colocaram no enfrentamento à pandemia com os poucos recursos disponíveis. Diante deste cenário, destacou-se o caso do Maranhão. 0 governo estadual fez algumas infrutíferas tentativas de compra internacional de respiradores para equipar os hospitais do Estado. Este esforço teve como obstáculo tanto o governo federal - que chegou a confiscar respiradores para distribuí-los segundo seus critérios - quanto outros países - que têm oferecido valores mais altos por cargas em curso de material médico e

\footnotetext{
${ }^{17}$ O Consórcio Interestadual de Desenvolvimento Sustentável do Nordeste é uma autarquia criada em 2019 que reúne os nove Estados daquela região em um empreendimento que visa à atração de investimentos de forma integrada desde a tentativa de viabilização dos recursos até a implementação de políticas públicas (LEITE, 2020). ${ }^{18}$ O Consórcio Interestadual de Desenvolvimento Sustentável da Amazônia Legal é uma autarquia criada em 2017 que reúne os nove Estados da chamada Amazônia Legal com intuito de incrementar o desenvolvimento sustentável na região por meio de projetos comuns desenvolvidos pelos associados (SECRETARIA EXECUTIVA AMAZONIA LEGAL, 2019).
} 
hospitalar (ALVARENGA et al., 2020). O governo do Maranhão optou, então, por uma rota alternativa e realizou a compra sem licenciamento da Agência Nacional de Vigilância Sanitária (ANVISA) ou autorização da Inspetoria da Receita Federal, tendo passado pelos trâmites da Receita quando já em solo maranhense (ALVARENGA et al., 2020) em uma insólita operação de importação de insumos à margem da burocracia federal.

A distensão entre o governo federal e as práticas estaduais também aparece nas relações comerciais. O Consórcio do Nordeste tem intensificado suas relações com a China, mesmo diante das insistentes críticas do Executivo Federal ao país. As transações comerciais entre os nove Estados do Consórcio e a China nunca foram tão intensas (MELLO, 2019). A parceria tem se estabelecido em um claro enfretamento ao Governo Federal, sendo anunciada de forma ruidosa em momentos em que o Executivo e seus aliados se manifestam publicamente contra o país (PRADO, JUNQUEIRA, 2020). A relação tem se intensificado no âmbito do combate à pandemia do COVID-19. Os governadores do Consórcio mantiveram contato diretamente com a Embaixada da China no Brasil sobre o enfrentamento da pandemia (FOLHA, 2020) em uma explícita demonstração de autonomia em relação ao governo federal.

Estes episódios demonstram o transbordamento da oposição política da cena nacional para o âmbito internacional. Eles seguem sendo uma faceta minoritária das ações paradiplomáticas dos governos subnacionais brasileiros. A regra permanece a de desenvolvimento de atividades internacional que não caracterizam uma oposição ao governo federal. Contudo, a recorrência da paradiplomacia de resistência comprova que se trata de um movimento que deve ser considerado e analisado tanto para a apreensão do quadro das atividades internacionais dos governos subnacionais brasileiros quanto para discussões acerca da institucionalização jurídica deste fenômeno. 


\section{REFLEXÕES SOBRE O QUADRO JURÍDICO BRASILEIRO DIANTE DA PRÁTICA DO FENÔMENO DA PARADIPLOMACIA}

O Direito é produto social. Das características da sociedade - incluindo seu contexto político, econômico - ele retira seu sustento. Isso, por um lado, afirma o dinamismo do fenômeno jurídico. Contudo, por outro lado, há um limite de tempo e profundidade para que sejam realizadas mudanças que resultem do processo legislativo. A paradiplomacia, ainda que possa parecer uma prática que simplesmente acompanha a mitigação das fronteiras, consequente da aceleração dos fluxos globais, é uma dinâmica que desafia fundamentos importantes do sistema westfaliano. Afinal, o monopólio da ação internacional dos governos centrais e a unicidade dos Estados são a base do sistema interestatal moderno. Por isso, refletir sobre a relação entre as ações internacionais dos governos subnacionais e o quadro normativo de um Estado é uma tarefa necessária e por vezes intrincada.

Enquanto outras federações optaram por normatizar sobre a paradiplomacia já no início da sistematização de suas manifestações - caso da Alemanha, Argentina, Áustria e Bélgica, por exemplo - o Brasil apenas criou normas no âmbito federal para casos específicos de cooperação. As tentativas de uma normatização mais ampla - PEC n 475 e Proposta de Substitutivo à Lei Complementar n 98 - não obtiveram êxito. Restou aos governos municipais e estaduais legislarem acerca do tema, ainda que de forma superficial, na maioria das vezes.

É interessante observar que as ações paradiplomáticas empreendidas pelos governos estaduais e municipais no Brasil mantêm-se no seu âmbito de competência, especialmente na esfera das competências comuns do supracitado artigo 23 da Constituição Federal ${ }^{19}$. Tanto a paradiplomacia tradicional quanto aquela aqui caracterizada como de resistência ao governo federal, cujos episódios foram narrados, baseiam-se em ações relacionadas ao âmbito de competência daqueles entes federados, previstas constitucionalmente. Assim, mesmo naquelas dinâmicas em que há um elemento discrepante das atividades paradiplomáticas

\footnotetext{
${ }^{19}$ Vide nota 10.
} 
tradicionais - o embate com o governo federal - há um elemento de continuidade - elas ocorrem como meio para a realização de uma competência comum disposta na Constituição.

Há, no Brasil, fundamentalmente duas correntes de pensamento acerca da relação que se estabelece entre o quadro jurídico nacional e a atividade paradiplomática. Uma delas sustenta que não há nada que impeça juridicamente a ação internacional de Estados e Municípios no âmbito de sua competência "desde que não contrariem o interesse nacional ou invadam a alta política" (RODRIGUES, 2008, p. 1017). Nesse sentido caminharam o parecer do relator da PEC $n^{\circ} 475$, deputado Ney Lopes, e parte dos autores que se debruçam sobre o tema como Rodrigues (2004; 2006), Fonseca (2013), Tavares (2014) e Aprígio (2016). Para estes autores, não há dificuldade com o atual quadro normativo nacional e a paradiplomacia. O meio - nacional ou internacional - para a realização da competência constitucionalmente atribuída ao ente federado não seria, portanto, fundamental para julgar sua constitucionalidade.

Outra corrente afirma que falta ao ordenamento jurídico brasileiro autorização para a assunção de compromissos internacionais aos governos subnacionais. Conforme Prazeres (2004, p. 303), "a boa exegese dos dispositivos constitucionais referentes à política externa não parece afastar a possibilidade de as unidades federadas defenderem seus interesses no plano internacional desde que não assumam compromissos jurídicos". Nesse sentido, de que não há produção de efeitos jurídicos para acordos pactuados por governos estaduais e municipais brasileiros, argumentam, além de Prazeres (2004), Lessa (2002) e Rosa (2013).

A resposta à problemática da constitucionalidade ou não da paradiplomacia no Brasil, especialmente no que concerne aos compromissos jurídicos assumidos pelos governos municipais e estaduais, passa por diferentes reflexões sobre o Direito, ainda pouco enfrentadas em todas as suas perspectivas pelos autores pátrios que dissertam sobre o tema. Primeiramente, não resta dúvida de que cabe efetivamente ao Direito interno e não ao Direito Internacional decidir sobre a possibilidade ou não de os governos subnacionais se engajarem em compromissos internacionais (REZEK, 1984; BROWNLIE, 1997; PELLET, 2003; SHAW, 2003). 
Assim, o Direito Internacional não se ocupa do tema, restando ao Direito de cada Estado Nacional definir sobre os contornos da paradiplomacia.

Conferir ao Direito nacional a normatização acerca da ação da Administração Pública estadual e municipal significa necessariamente refletir sobre algumas perspectivas do Direito Constitucional e Administrativo. No texto constitucional devem ser apostas as competências de cada ente público que participa do Estado (CANOTILHO, 2007). Para advogar-se a favor da ideia de que o ordenamento brasileiro já concede permissão para ação internacional dos governos subnacionais, é preciso inferir que as disposições constitucionais acerca das competências de entes federativos, ainda que sem menção ao âmbito internacional, são suficientes para anuir a atividade internacional. Assim, realizando-se uma atividade que vise à consecução de um dever disposto constitucionalmente, seja do Município ou do Estado membro, pouco importaria se esta se realiza em território nacional ou por meio de contatos e assunção de compromissos que perpassam as fronteiras nacionais. Para a corrente que nega a constitucionalidade dos compromissos internacionais dos governos subnacionais, haveria a necessidade de autorização constitucional expressa, específica para o engajamento com entes estrangeiros e internacionais.

Uma consequência dessa distensão na perspectiva constitucional, ou seja, na compreensão de que a previsão de competências, tal qual disposta no texto constitucional, seria suficiente ou não para legitimar as ações paradiplomáticas, está no âmbito do Direito Administrativo. Ainda que não haja muitas discussões a este respeito, uma das possíveis justificativas para a considerar-se que não há autorização constitucional para a paradiplomacia relaciona-se ao princípio da legalidade, tão caro à Administração Pública. Segundo este princípio, a "Administração Pública só pode fazer o que a lei permite" (DI PIETRO, 2017, p. 96). A pergunta é se, para ser cumprido o princípio da legalidade, seria essencial que a Constituição fosse expressa em relação à possibilidade de ação internacional dos governos municipais e estaduais. Quando se busca a hermenêutica e o conteúdo axiomático do princípio da legalidade, parece não ser ele um óbice para a consecução da paradiplomacia. Como explica Di Pietro (2017, p.96), este princípio exprime que "a 
Administração Pública não pode, por simples ato administrativo, conceder direitos de qualquer espécie, criar obrigações ou impor vedações aos administrados; para tanto, depende da lei". Ora, como fica claro a partir da exposição sobre as características da paradiplomacia brasileira, essas ações não são o objeto costumaz das atividades paradiplomáticas. E caso sejam praticadas, devem ser averiguadas, tal qual ocorreria em caso de uma atividade lesiva da Administração Pública empreendida em território nacional.

Assim, compreendendo-se a paradiplomacia como meio para a consecução de competências constitucionalmente previstas das unidades subnacionais e enfrentada a questão do Princípio da Legalidade, torna-se possível conceber a viabilidade constitucional das ações dos governos municipais e estaduais para além das fronteiras nacionais. Esta parece ser a posição mais recente do Itamaraty sobre a paradiplomacia. Apesar da histórica afirmação acerca do monopólio da ação internacional da União - mitigada, segundo os pareceres, somente em caso de acordos-quadro que admitem a cooperação subnacional - a mais recente manifestação sobre a paradiplomacia é a mais favorável já emitida sobre este tema. Em artigo de 2014, Rodrigo Tavares, então Assessor Especial para Assuntos Internacionais do Estado de São Paulo, cita uma resposta formal do Itamaraty, produzida a partir de questionamentos da Administração paulistana sobre o fenômeno da paradiplomacia. O documento, de 2013, é pouco citado e pouco discutido. Segundo Tavares, nele, o Itamaraty argumenta que a "falta de institucionalização jurídica" da paradiplomacia não inibe sua atuação; que o MRE dá respaldo das atividades que se estabelecem no âmbito de competência dos Estados e Municípios; que as consultas à União devem ser realizadas quando houver transferência de recursos financeiros; e que os acordos internacionais realizados por entes subnacionais "fazem parte do ordenamento jurídico interno" (TAVARES, 2014, p. 25).

A resposta do Itamaraty faz coro à ideia de que o silêncio da Constituição sobre a ação internacional dos governos subnacionais não deve ser interpretado como uma recusa à paradiplomacia. Há, sim, como parece razoável, limites de competência e, no caso de financiamentos, faz-se necessária a anuência da União - restrições inteligíveis a partir dos dispositivos constitucionais. A conclusão pela viabilidade jurídica das atividades 
paradiplomáticas não retira, contudo, a fragilidade consequente da ausência de um marco jurídico que a acompanhe. Nesse sentido, pesa, especialmente a possibilidade de proposição e aprovação de uma legislação que possa engessar ou reduzir as atividades internacionais realizadas pelos governos municipais e estaduais.

É preciso refletir sobre a relação que se estabelece entre os limites normalmente apostos à paradiplomacia em termos jurídicos - e que estão presentes nas legislações já propostas no Brasil sobre o tema - e as características desse fenômeno no país. Esse exame permite ponderar sobre as repercussões que teriam advindo da aprovação das legislações que tramitaram pelo Congresso o que, como consequência, oferece bases sólidas para discussões sobre a normatização do tema. Preocupa, especialmente, os termos da necessidade de aprovação prévia das ações internacionais de Estados e Municípios pelo poder central. Eventual aprovação realizada por órgão do governo federal - possivelmente o MRE - deveria recair somente sobre os atos internacionais que levem à realização de compromissos jurídicos de Estados e Municípios. Não parece razoável que atos de mera representação ou defesa de interesses precisem passar pelo crivo do governo federal. Uma providência importante para que a dinâmica da atividade paradiplomática seja respeitada, seria a proposição explícita de um fluxo temporal deste processo de apreciação, o que se justifica pelo grande número de subunidades federadas existentes no Brasil.

Finalmente, em tempos de intensa polarização política, como a atual, tem-se clareza sobre as graves restrições que, valendo-se da paradiplomacia, poderiam ser impostas a governos que se opõem politicamente ao governo federal. Por isso, a perspectiva de que o MRE precise autorizar as ações da paradiplomacia deve ser acompanhada da concepção de que as negativas do Ministério deveriam ser motivadas e restritas a casos em que as ações ultrapassem as competências do ente federado. Mesmo limitações às "atividades contrárias ao interesse nacional" devem ser evitadas já que a carga de discricionariedade contida nesse tipo de jargão pode ser usada como um obstáculo à paradiplomacia diretamente e, indiretamente, e mais importante, à realização das competências constitucionalmente previstas aos Estados e Municípios. 


\section{CONCLUSÃO}

A paradiplomacia é um fenômeno que auxilia os governos subnacionais brasileiros a realizarem suas competências, contando, para tanto, com a arena internacional. O contato com seus homólogos, organizações internacionais e outras instituições estrangeiras e internacionais, públicas e privadas fornece subsídios financeiros e técnicos, fomentando a capacidade de Estados e Municípios lidarem com os desafios da Administração Pública. Tradicionalmente, as ações paradiplomáticas dos entes subnacionais brasileiros ocorrem sem dissensos com o governo federal. Contudo, a recente e intensa polarização política tem levado especialmente os Estados a incursões que desafiam a agenda federal, ainda que por meio de ações em que os âmbitos de competência são respeitados.

Diante das novas dinâmicas da paradiplomacia, este artigo revisitou o quadro normativo brasileiro sobre a temática. Poucas normas sobre esta matéria foram aprovadas até o momento. Uma tentativa de emendar a Constituição Federal e uma proposta de legislação infraconstitucional não foram adiante no Congresso Nacional. As disposições aprovadas, as rejeitadas e as características da atividade paradiplomática no Brasil colaboram para formar a equação que se pretendeu aqui construir afim de melhor compreender as relações que se estabelecem entre um quadro normativo para a paradiplomacia e sua prática.

O caminhar da paradiplomacia no Brasil tem demonstrado que a arena internacional pode e deve ser um ambiente considerado pelos entes públicos federados para desenvolver suas competências constitucionalmente previstas. As recentes incursões dos governadores ao sistema internacional tendo como objetivo fomentar políticas públicas regionais nos âmbitos do desenvolvimento econômico, preservação ambiental e incremento da saúde - ainda que em contraposição ao governo federal, e talvez especialmente por isso - apenas corroboram a importância da atividade paradiplomática como instrumento da gestão pública. A importância deste fenômeno, em termos concretos e potenciais, torna necessárias reflexões que auxiliem no seu desenvolvimento, contribuindo para que a paradiplomacia se torne mais robusta e 
profunda em um ambiente político e jurídico preparado para acomodá-la em sua complexidade e em seus limites.

\section{REFERÊNCIAS}

ABRAHAM, Leonardo Díaz La cooperación descentralizada pública en México: La hora ha llegado. In: Anuario de la cooperación descentralizada 2006. Observatorio de Cooperación Descentralizada Unión Europea - América Latina: Montevideo, 2007, p. 280.

AFFONSO, Rui. A crise da federação no Brasil. In: Ensaios. FEE - Fundação de Economia e Estatística, Porto Alegre, n. 2, 1994. p. 321-337.

ALEMANHA. [Lei Fundamental da República Federal da Alemanha (1949)]. Grundgesetz für die Bundesrepublik Deutschland. Bonn: Deutscher Bundestag, 1949.

ALVARENGA, Alexandre et al. Desafios do Estado brasileiro diante da pandemia de COVID-19: o caso da paradiplomacia maranhense. Cadernos de Saúde Pública, 36 no.12, Rio de Janeiro, Dezembro 2020.

APRIGIO, André. Paradiplomacia e interdependência: as cidades como atores internacionais. Rio de Janeiro: Gramma, 2016.

AUSTRIA. [Constituição da Áustria (1920)]. Österreichische Bundesverfassung. Viena: Österreichisches Parlament, 1920.

BANZATTO, Arthur. A Inserção Internacional dos Governos Não Centrais Brasileiros e Argentinos em Perspectiva Comparada. Dissertação de Mestrado. Programa de PósGraduação em Relações Internacionais, Instituto de Relações Internacionais da Universidade de Brasília. 2015.

BARRETO, Maria Inês. Estratégias de governos subnacionais frente ao desafio da internacionalização: o caso do Estado de São Paulo. In: VI Congreso Internacional del CLAD sobre la Reforma del Estado y de la Administración Pública. Buenos Aires, 2001.

BELGICA. [Constituição da Bélgica (1831)]. La Constitucion Belge. Bruxelas: Senate, 1831.

BRANCO, Álvaro Chagas Castelo. A paradiplomacia como forma de inserção dos entes não centrais no cenário internacional. 2006. Dissertação (Mestrado). Programa de Mestrado em 
Direito. Universidade de Brasília, 2006.

BRASIL. [Constituição (1988)]. Constituição da República Federativa do Brasil. Brasília: Senado, 1988.

BRASIL. Decreto no 7400 de 22 de dezembro de 2010. Brasília: Planalto, 2010.

BRASIL. Decreto no 9139 de 22 de agosto de 2017. Brasília: Planalto, 2017.

BRASIL. Decreto no 9683 de 9 de janeiro de 2019. Brasília: Planalto, 2019.

BRASIL. Projeto de Emenda à Constituição no 475, 2005. Brasília: Câmara, 2005.

BRASIL. Proposta de Substitutivo ao Projeto de Lei do Senado no 98, 2006. Brasília: Senado, 2006.

BROWNLIE, Ian. Princípios de Direito Internacional Público. Lisboa: Fundação Calouste Gulbenkian, 1997.

BUENO, Ironildes. Paradiplomacia Contemporânea: trajetórias e tendências da atuação internacionais dos governos estaduais do Brasil e dos EUA. Tese de Doutorado. Brasília: Universidade de Brasília, 2010.

BRIGAGÃO, Clóvis. Relações Internacionais Federativas do Brasil - Estados e Municípios. Rio de Janeiro: Gramma, 2005.

CAMARA dos Deputados. Relatório ao Projeto de Emenda à Constituição 475/2005. Brasília: Comissão de Constituição e Justiça e de Cidadania, 2006.

CANOTILHO, J. J. Gomes. Direito Constitucional e Teoria da Constituição. Coimbra: Almedina, 2007.

CNM. Observatório da Cooperação Descentralizada no Brasil. Brasília: CNM, 2009.

DI PIETRO, Maria Sylvia. Direito Administrativo. Rio de Janeiro: Forense, 2017.

DUCHACEK, Ivo. Perforated sovereignties: towards a typology of news actors in international relations. In: SOLDATOS, Panayotis; MICHELMANN, Hans (Eds.). Federalism and International Relations: the role of subnational units. New York: Oxford University Press, 1990, p. 1-33. 
DW. Mourão recria Fundo Amazônia, mas Alemanha e Noruega não garantem recursos. DW. 29 de maio de 2020. Disponível em: https://www.dw.com/pt-br/mour\%C3\%A3o-recriafundo-amaz\%C3\%B4nia-mas-alemanha-e-noruega-n\%C3\%A3o-garantem-recursos/a53621619. Acesso em: 01 de dez. 2020.

EUA. [Constituição (1876)]. Constitution of the United States. Washington: Senate, 1876.

FOLHA. Governadores do NE acenam a embaixada da China em meio a crise com Eduardo. Folha de São Paulo. 21 de março de 2020. Disponível em: https://www1.folha.uol.com.br/mundo/2020/03/governadores-do-ne-acenam-aembaixada-da-china-em-meio-a-crise-com-eduardo.shtml. Acesso em: 02 dez. 2020

FONSECA, Marcela Garcia. Os entes federativos brasileiros frente ao Direito Internacional. 2013. Tese (Doutorado). Programa de Pós-Graduação em Relações Internacionais, Universidade de São Paulo, São Paulo, 2013.

FRÓIO, Liliana Ramalho. Paradiplomacia e o impacto da alternância de governos na atuação internacional dos estados brasileiros. 2015. Tese (Doutorado). Programa de Pós-graduação em Ciência Política, Universidade Federal de Pernambuco, 2015.

IBGE. Perfil dos Municípios Brasileiros, 2012. Rio de Janeiro: 2013.

IBGE. Estimativa de população dos Municípios para 2020. Disponível em: https://agenciadenoticias.ibge.gov.br/agencia-sala-de-imprensa/2013-agencia-denoticias/releases/28668-ibge-divulga-estimativa-da-populacao-dos-municipios-para-2020. Acesso em: 03 de dez. 2020

INPE. A estimativa da taxa de desmatamento por corte raso para a Amazônia Legal em 2019 é de 9.762 km². Disponível em: http://www.inpe.br/noticias/noticia.php?Cod Noticia=5294. Acesso em: 01 dez. 2020

ITAMARATY. Parecer sobre o Protocolo Adicional ao Acordo Básico de Cooperação Técnica entre o Governo da República Francesa e o Governo da República Federativa do Brasil sobre a Cooperação Descentralizada. Itamaraty: Brasília, 2008.

ITAMARATY. Parecer sobre o Protocolo Adicional ao Acordo Básico de Cooperação Técnica entre o Governo da Itália e o Governo da República Federativa do Brasil sobre a Cooperação Descentralizada. Itamaraty: Brasília, 2008.

JUNQUEIRA, Cairo. Paradiplomacia: a transformação do conceito nas relações internacionais 
e no Brasil. BIB, São Paulo, n. 83, 10 semestre de 2017, p. 43-68.

KEATING, M. Regions and international affairs: motives, opportunities and strategies. In: Fransisco Aldecoa and Michael Keating (Eds). Paradiplomacy in Action: The Foreign Relations of Subnational Governments. London: Frank Cass, 1999, p. 1-17.

KUZNETSOV, Alexander S. Theory and practice of paradiplomacy: subnational governments in international affairs. New York, NY: Routledge, 2015.

LEITE, Sérgio. O Consórcio. Disponível em: http://www.consorcionordeste-ne.com.br/oconsorcio/. Acesso em 12 jul. 2021.

LESSA, José Vicente. A paradiplomacia e os aspectos legais dos compromissos internacionais celebrados por governos não-centrais. Brasília: MRE, 2002.

MAIA, José Nelson Bessa; SARAIVA, José Flávio Sombra. A paradiplomacia financeira no Brasil da República Velha, 1890-1930. RBPI, 55 (1), 2012.

MAGALHAES, José Luiz Quadros de. O Pacto Federativo. Belo Horizonte: Mandamentos, 2000.

MARCOVITCH, Jacques; DALLARI, Pedro B. A. Relações Internacionais de Âmbito Subnacional: A Experiência de Estados e Municípios no Brasil. São Paulo: USP, 2014.

MATSUMOTO, Carlos Eduardo Higa. As Determinantes Locais da Paradiplomacia: o caso dos municípios brasileiros. 2011. Dissertação (Mestrado). Programa de Pós-Graduação em Relações Internacionais Universidade de Brasília, Brasília, 2011.

MEDEIROS, Antônio Paulo Cachapuz de (Org.). Pareceres dos Consultores Jurídicos do Itamaraty - 1934-1946. Brasília: Senado Federal, v.3, 2000.

MEDEIROS, Antônio Paulo Cachapuz de (Org.). Pareceres dos Consultores Jurídicos do Itamaraty - 1946-1951. Brasília: Senado Federal, v.4, 2000.

MEDEIROS, Antônio Paulo Cachapuz de (Org.) Pareceres dos Consultores Jurídicos do Itamaraty - 1961-1971. Brasília: Senado Federal, v.6, 2000.

MELLO, Patrícia Campos. Rebeldes, estados brasileiros driblam Bolsonaro. Folha de São Paulo. 27 set. $2019 . \quad$ Disponível em: https://www1.folha.uol.com.br/colunas/patriciacamposmello/2019/09/rebeldes-estadosbrasileiros-driblam-bolsonaro.shtml. Acesso em: 01 dez. 2020 
MIKLOS, Manoela. Diplomacia Federativa: o Estado Brasileiro e a Atuação de suas Unidades Constituintes. Carta Internacional. Vol. 6, n. 1, jan.-jun. 2011, p. 83 a 100.

PELLET, Alain et al. Droit International Public. 7a ed, Paris: L.G.D.J, 2002.

PRAZERES. Tatiana Lacerda. Por uma atuação constitucionalmente viável das unidades federadas brasileiras ante os processos de integração regional. In: VIGEVANI, Tullo et al (Org.). A dimensão subnacional $\mathrm{e}$ as relações internacionais. São Paulo: EDUC/UNESP/EDUSC/FAPESP, 2004.

PRADO, Debora. A atuação internacional dos governos subnacionais: construções conceituais, limites e contribuições para o caso brasileiros. Rev. Carta Inter. Belo Horizonte, v.13, n.3, 2018, p. 137-168.

PRADO, Débora; JUNQUEIRA, Cairo G. B. A queda de braço entre governadores e Bolsonaro. Le Monde Diplomatique Brasil. 26 mar. 2020. Disponível em: https://diplomatique.org.br/aqueda-de-braco-entre-governadores-e-bolsonaro/. Acesso em: 02 dez. 2020.

REZEK, Francisco. Direito dos tratados. Rio de Janeiro: Forense, 1984.

REZEK, Francisco. Direito Internacional Público. São Paulo: Saraiva, 2005.

RIPSMAN, N. M. False Dichotomy: When Low Politics is High Politics. Paper presented at the ISA Annual Meeting, Montreal, Quebec, Canada, Mar 17, 2004

RODRIGUES, Gilberto. A inserção internacional de cidades: notas sobre o caso brasileiro. In: VIGEVANI, Tullo et al. (Org.). A dimensão subnacional e as relações internacionais. São Paulo: EDUC/UNESP/EDUSC/FAPESP, 2004. p. 441-462.

RODRIGUES, Gilberto. Relações Internacionais Federativas no Brasil. Dados - Revista de Ciências Sociais, Rio de Janeiro, Vol. 51, n. 4, 2008, p. 1015-1034.

ROMERO, Maria Del Huerto. Uma aproximación conceitual y contextual de la cooperación descentralizada. In: ZÚÑIGA, Victor; ROMERO, Maria del Huerto (Orgs.). Tejiendo lazos entre territórios: la cooperación descentralizada local Unión Europea-América Latina. Valparaíso: 2004, p. 19-51. 
ROSA, Leonardo Barchini. A Secretaria Municipal de Relações Internacionais e Federativas da Prefeitura Municipal de São Paulo. In: MARCOVITCH, Jacques; DALLARI, Pedro B. A. Relações Internacionais de Âmbito Subnacional: A Experiência de Estados e Municípios no Brasil. São Paulo: Instituto de Relações Internacionais-Universidade de São Paulo, 2014, p. 57-72.

SASSEN, Saskia. El Estado y la nueva geografia del poder. In: Perdiendo el Control? La Soberania en la Era de la Globalizacion. Espanha: Edicions Bellaterra, 2001, p.48-72

SCHIAVON, Jorge. Comparative paradiplomacy. New York, NY: Routledge, 2019. SECRETARIA EXECUTIVA AMAZONIA LEGAL. Relatório de Gestão 2019. Disponível em:https://www.tce.ap.gov.br/relatorio gestao/Cons\%C3\%B3rcio\%20Interestadual\%20de\% 20Desenvolvimento\%20Sustent\%C3\%A1vel\%20da\%20Amaz\%C3\%B4nia\%20Legal\%20\%202019.pdf. Acesso em 12 jul. 2021.

SENADO Federal. Relatório à Proposta de Substitutivo ao Projeto de Lei do Senado no 98/2006. Brasília: Senado, 2010.

SHAW, Malcolm. International Law. Cambridge: Cambridge University Press, 2003.

SOLDATOS, Panayotis. An Explanatory Framework for the study of Federated States as Foreign Policy Actors. In: SOLDATOS, Panayotis; MICHELMANN, Hans (Ed.). Federalism and International Relations: the role of subnational units. Oxford: Clarendon Press, 1990, p. 3453.

SUIÇA. [Constituição (1999)]. Constitution fédérale de la Confédération suisse. Berna: Assemblée fédérale, 1999.

TAVARES, Rodrigo. As Relações Internacionais do Estado de São Paulo. In: MARCOVITCH, Jacques; DALLARI, Pedro. Relações Internacionais de Âmbito Subnacional: A Experiência de Estados e Municípios no Brasil. São Paulo: Instituto de Relações Internacionais - USP, 2014, p. 12-27.

TAVARES, Rodrigo. Paradiplomacy: cities and states as global players. New York: Oxford University Press, 2016. 